\title{
SIR MARC ARMAND RUFFER (1859-1917) PIONEER OF PALAEOPATHOLOGY
}

\author{
by
}

\section{A. T. SANDISON}

FIFTY YEARS have elapsed since the death of Sir Marc Armand Ruffer and it would seem proper at this time to pay tribute to his memory and to re-assess the influence of his palaeopathological studies in the continuing development of that subject.

Ruffer was born at Lyons in France in $\mathbf{1 8 5 9}$ and was the son of Baron Jacques de Ruffer (member of a well-known banking family) and of a German mother. His early education took place in France and Germany but he later came to England where he graduated in arts from Brasenose, Oxford, and in medicine at London. He studied for a short time at the Pasteur Institute, while Pasteur and Metchnikoff were actively working there.

At this period he was interested mainly in the pathology and micro-biology of inflammation and in 1891 he became first director of the British Institute of Preventive Medicine (now the Lister Institute). While investigating the diphtheria bacillus Ruffer became infected with the disease and suffered such severe paralytic sequelae that he was compelled to resign his post and went to convalesce in Egypt. He took up residence in Ramleh and in due course was appointed Professor of Bacteriology at Cairo. He later became President of the Sanitary, Maritime and Quarantine Council of Egypt and one of his major achievements was the elimination of cholera from the country by measures enforced at the El Tor Quarantine Station and elsewhere. He also served on the Indian Plague Commission and at the outbreak of the First World War he became head of the Red Cross in Egypt. He received his knighthood in 1916 and in December of that year went to Salonika to reorganize the Sanitary Service of the Greek Provisional Government. While returning to Egypt from Salonika he died at sea in the spring of 1917; the exact date appears to be in doubt. His wife, Alice Mary, Lady Ruffer, daughter of a British Army Officer, continued to live in Alexandria and died there on 11 January 1950 at the age of 80 .

Ruffer (not surprisingly in view of his education) was a linguist of ability although he had no special knowledge of Arabic, a not inconsiderable player on the violoncello and, somewhat incongruously perhaps, an expert billiards player. He was a man of quiet disposition, quaint humour and old-world courtesy. He was not a man of many words but was heard with great respect. He was an ideal colleague, unselfish and ever ready to help and advise others. He endeared himself to all with whom he came into contact. (Garrison, 1917; Plimmer, 1917; Ritchie and Williamson, 1918-19; Moodie in Ruffer, 1921).

It is, therefore, clear that Sir Marc Ruffer would be worthy of remembrance in respect of his service as a bacteriologist and hygienist of international repute. His fame, however, rests rather on his pioneer works in palaeopathology. He was clearly fascinated by the wealth of human remains being discovered in Egypt and published 


\section{Sir Marc Armand Ruffer (1859-1917)}

a remarkable series of papers commencing in 1909. These appeared fairly regularly until his death, and thereafter Lady Ruffer issued five more posthumous articles up to the year 1920. All of these articles were gathered together and published in book form under the devoted editorship of Roy L. Moodie in 1921. This book entitled Studies in the Palaeopathology of Egypt has, unfortunately, long been out of print and it would be of great service if a reissue could be arranged.

Probably no book has had a comparable effect on palaeopathology and these papers have been widely studied and repeatedly quoted by all workers in this discipline. Ruffer's influence has without doubt been enormous and his essays have fired the imagination of all students of diseases in antiquity and of medical historians in general. The subjects vary widely but the majority are concerned with actual pathological conditions in ancient Egyptian remains.

The first group comprises three histological studies of merit (Ruffer, 1909, 1910a, 1911a). Strangely enough, although Ruffer's name will always be linked with pioneer work in palaeohistology, he was by no means the first to pursue such studies. About sixty years previously Czermak (1852) had teased out Egyptian mummy tissues, e.g. tendon, cartilage, nerve, muscle, fat, etc., in caustic soda solution and had made excellent drawings of their microscopic structure. Moodie (in Ruffer 1921) points out that Fouquet had pioneered actual sections of mummy tissues for microscopy as early as 1889. Wilder (1904) studied dried tissues from Peruvian, Cliff-dweller and Basketmaker American Indian bodies and Shattock (1909) prepared frozen sections of the aorta of Pharaoh Merneptah of the nineteenth dynasty.

Nonetheless, Ruffer made the first important observations and devised a softening fluid for the rehydration of brittle mummy tissues necessary before they can be processed for microtome sectioning. Wilson (1927) used a similar fluid. A modification of this fluid is still widely used for similar palaeohistological purposes (Sandison, 1955, Ryder, 1958, Rowling, 1961) and has been used in the investigation of modern mummified forensic medical material (Evans 1961).

Probably no paper on palaeohistological studies has since appeared without reference to Ruffer's pioneer work. Histological techniques have, of course, improved greatly since Ruffer worked in Egypt and these have been applied to palaeohistology (Sandison, 1955, 1957, 1959, 1963a). It is now relatively simple to obtain better sections and to use more efficient differential and specific staining methods than were available to Ruffer. The contemporary palaeohistologist has also the advantage of improved photographic techniques for recording his findings. They present Ruffer's illustrations (often drawn and tinted by his devoted wife) in a rather old-fashioned light but these are supplemented by clear descriptions which leave no doubt of the accuracy of Ruffer's tissue diagnosis. Further the abundance of the material at his disposal has never been available to later workers and it is possible that some of his studies may never be able to be repeated.

Ruffer's conclusions can only rarely be faulted although I believe that he was, perhaps, over-optimistic in his belief that histological observations permitted opinion as to methods of embalming in ancient Egypt (Sandison, 1963b).

Following these basic observations on normal histological structures Ruffer made unprecedented and unrivalled observations in the pathological histology of mummy 


\section{A.T. Sandison}

tissues. Perhaps the most important was his discovery of the calcified eggs of Schistosoma haematobium bilharzia in the straight tubules of the kidneys of two twentieth dynasty Egyptian mummies (Ruffer, 1910b). This observation is of cardinal importance since it extends back the history of schistosomiasis for three millenia and substantiates the statements in the great medical papyri from ancient Egypt that haematuria was common. I suppose this might be regarded as the foundation of a new science of palaeoparasitology; this science has recently been extended by qualitative and quantitative assessments of helminth ova astonishingly well preserved in medieval cesspits and latrine deposits (Pike, in press).

A further paper of fundamental importance concerns the histological study of arterial lesions in Egyptian mummies (Ruffer, 1911b). This demonstrated unequivocally the presence of atheromatous degenerative arterial disease in bodies from the eighteenth dynasty of the New Kingdom until the Coptic Christian period. Ruffer suspected, but was unable to demonstrate satisfactorily, hypertensive arteriosclerosis but the latter has since been shown by Sandison (1962) who also confirmed Ruffer's findings of atheroma and calcification.

Ruffer and Ferguson (1911) studied a skin eruption from a twentieth dynasty mummy. This eruption in distribution, pattern and type closely resembled that of smallpox and histological section showed vesicles with vertical septae consistent with the appearances seen in that disease. This diagnosis has not the absolute certainty of the previously mentioned cases of schistosomiasis and atheroma but is reasonably probable.

Elliot Smith and Ruffer (1910) had previously published a most important paper describing Pott's disease in an Egyptian mummy of the twenty-first dynasty. There is, and has been, much debate concerning tuberculosis in ancient societies. Derry (1909) had described skeletal remains which he believed to show evidence of tuberculosis and had further reviewed them in 1938; these remains have since been re-examined by Rowling (1960) who confirmed Derry's diagnosis. Morse, Brothwell and Ucko (1964) have critically reviewed the evidence for tuberculosis in ancient Egypt. They accepted thirty-one cases, sixteen of which had previously been reported, while fifteen were new. The importance of the paper of Elliot Smith and Ruffer is that in the mummy examined by them the soft tissues were preserved and the tracking of the psoas infection could be confirmed. This puts the diagnosis of tuberculosis beyond any reasonable doubt and lends weight to the other evidence derived from skeletal remains and artistic representations of hunch-back. Notwithstanding a statement in his obituary notice in the Lancet to the contrary, Ruffer did not succeed in demonstrating the tubercle bacillus in mummy tissues.

Of less importance is a study of two mummies from the period of Persian occupation (Ruffer and Rietti, 1912a). This is of largely Egyptological importance. More relevant was the study of dried bodies from the Coptic period (Ruffer, 1913). These bodies were not embalmed in the conventional sense since mummification had been abandoned with the advent of the Christian religion. Ruffer gives useful accounts of the macroscopic and microscopic appearances of the internal organs, e.g. brain, lungs, heart, liver, kidneys, etc. There is also useful information on the pathology of the bones and teeth; this will be considered later. 


\section{Sir Marc Armand Ruffer (1859-1917)}

The last paper in this group (Ruffer, 1914a) concerns the Royal Mummies in Cairo Museum. These had been adequately described within the limits of permissible investigation by Elliot Smith (1912). Ruffer, however, compiles some useful data on such changes as baldness, comedone formation, ulcers and skin eruptions.

The next group of papers is of great importance. These include studies of osseous lesions in ancient Egyptians (Ruffer and Rietti, 1912b), of arthritis deformans and spondylitis in ancient Egypt (Ruffer, 1918a) and on abnormalities and pathology of ancient Egyptian teeth (Ruffer, 1920a). These papers complemented previous valuable works from Grafton Elliot Smith and Frederick Wood Jones (1910) describing the human remains from Nubia uncovered in the archaeological surveys of 1907-8.

The osseous lesions studied by Ruffer and Rietti occurred in skeletons and mummies presented to them by the Egyptologists, Maspero, Flinders Petrie, Keatinge and Breccia. The material included remains from Upper Egypt and from the tombs, near Alexandria, of the soldiers of Macedonian and other races in the armies of Alexander the Great and Ptolemy I.

Many of these remains showed, especially in the axial skeleton, evidence of spondylitis deformans (sic); this condition is now usually termed osteoarthritis although in the past the name arthritis deformans has also been used; this is a very common degenerative disease. Among other changes noted was myositis ossificans.

The remains studied varied very considerably in age-from the third, twelfth and twenty-second dynasties, the Persian, Macedonian and Roman occupations of Egypt and the Coptic Christian era; they cover a span of about 3000 years. This work confirmed and supplemented that of Elliot Smith and Wood Jones mentioned above. Not only was arthritic change frequent but dental disease was also abundant.

These findings were further confirmed and greatly amplified and illustrated in the later papers on arthritis and on abnormalities and pathology of the teeth. These three articles make a valuable compendium and together total 142 royal octavo pages and 23 photogravure plates.

They are further supplemented on a smaller scale by papers on pathologic lesions in Coptic bodies (1913) in which osseous and very severe dental changes are considered at some length and illustrated by two plates. Similarly, in a paper on diseases of the Sudan and Nubia in ancient times (Ruffer, 1914b), there are accounts of diseases of bone and teeth in remains of New Kingdom and Meroitic date.

The importance of this work of Elliot Smith, Wood Jones and Ruffer on arthropathy is that it established a mass of evidence for disease of the joints throughout the long period of Egyptian history. As mentioned above, this arthropathy is now recognized to be asteoarthritis: earlier papers (including those of Ruffer) used such terms as spondylitis deformans. These are undesirable since they may be confused with an entirely different and much more serious disease called ankylosing spondylitis. I have discussed such semantic problems at length elsewhere (Sandison, in press) and reiterate that osteoarthritic changes have been noted in ancient remains from a wide span of time and from very many geographic locations.

An interesting sidelight on arthritic changes in antiquity comes from the study of fossil animals, many of which also show osteoarthritis. In a posthumous paper (Ruffer, 1920b) there is a useful review of the literature up to that time and an interes- 


\section{A. T. Sandison}

ting account of arthritic change in the spine of a lower Miocene fossil crocodile from the desert. This is a fairly minor publication when compared with the compendious observations of Moodie $(1923,1931)$ and others, but it is still quoted and it is, indeed, the opening reference in a recent valuable critical review of the historical and prehistorical background of ankylosing spondylitis made by Zorab (1961).

At this point we may briefly notice a short paper (Ruffer and Willmore, 1914) describing a tumour in an isolated pelvic bone dating from the Roman period and recovered from the catacombs of Kom el Shougafa near Alexandria. Ruffer considered that this tumour might have been an osteosarcoma but was not dogmatic on this point. Others have considered it to be chondromatous; the diagnosis must remain open, but I think it may have been a chondrosarcoma.

In 1911 Ruffer published an interesting, well-illustrated and somewhat unusual paper, based on literary and artistic sources, concerning dwarfs and other deformed persons in ancient Egypt (Ruffer, 1911c). He showed clearly that Egyptologists had been in error when they assumed that ancient Egyptian dwarfs were African pygmies: they were in fact achondroplastics and Ruffer clearly established that achondroplasia has occurred over a period of five millenia. A later study by Dawson (1927) further develops this study. Ruffer also analysed representations of talipes, Pott's disease and possible rachitic deformity. A further interesting section concerns the diagnosis of the condition represented by the celebrated Queen of Punt. Ruffer (perhaps wisely) left this question open but refuted steatopygia and achondroplasia as being implicated. The most recent diagnosis comes from Wells (1964) who suggests bilateral congenital dislocation of the hip but admits that other possibilities exist.

A second paper similarly based on literary and artistic sources concerns consanguineous marriage in the royal families of the New Kingdom and Ptolemaic Egypt (Ruffer, 1919). This study clearly shows that such consanguineous marriages (provided that the stock is good) need not necessarily lead to ill-effects. In this paper there are statements of minor importance which will not be universally acceptable. For example, Ruffer in his preamble states that II Samuel 13, evidences permissive marriage between Hebrew half-brother and sister, whereas the relevant episode is the incestuous rape of Tamar by her half-brother Amnon. Further Ruffer does not make it clear that incestuous marriage among the common people in Egypt probably did not occur in Pharaonic times although it certainly did in the Hellenistic period. This valuable paper is still quoted in modern discussions on consanguineous marriage (Bourne, 1963).

The last paper we consider is rather different in scope. It is a posthumous review of the literature concerning prehistoric trephining (Ruffer, 1918b). It is clear that this is incomplete and that Ruffer intended to amplify it and to include further personal observations. It suffers from these deficiencies and is, perhaps, one of the less effective and less well known of Ruffer's works.

\section{CONCLUSIONS}

F. H. Garrison (1917) made a statement in his memorial notice of Sir Marc Armand Ruffer which has turned out to be truly prophetic. 'He had already prepared a volume ... which will probably be a permanent record of his unique and memorable dis- 
coveries in palaeopathology'. Lady Ruffer and Roy Moodie made the production of this volume possible and the passage of fifty years has confirmed Garrison's prescience in every respect. It would be a suitable memorial to Ruffer on this fiftieth anniversary of his death if this unique volume, long out of print, might again be made available to students of palaeopathology and medical history.

\section{REFERENCES}

BOURNE, A. W., 'Consanguineous marriage', Brit. med. J., 1963, ii, 1590-1591.

CzERMAK, J. N., 'Beschreibung und mikroskopische Untersuchung zweier ägyptischer Mumien', S. B. Akad. Wiss., Wien, 1852, 9, 427-469.

Dawson, W. R., 'Dwarfs and hunchbacks in Ancient Egypt,' Ann. Med. Hist., 1927, 9, 315-326.

Derry, D. E.. Archeol. Surv. Nubia, Bull. 3 and 4, Cairo, 1909.

Idem., 'Pott's disease in Ancient Egypt', Med. Press, 1938, i, 196-199.

Evans, E. G., 'The "Mummy Case", Pathological Investigations', Med. Sci. and Law, 1961, 2, 33-47.

Garrison, F. H., 'Memorial Notice Sir Marc Armand Ruffer, Kt., C.M.G. (1859-1917)', Ann. Med. Hist. 1917, 1, 218-220.

MoodIE, R. L., Paleopathology, Urbana, Illinois, 1923.

Idem., Roentgenologic Studies of Egyptian and Peruvian mummies, Chicago, 1931.

Morse, D., Brothwell, D. R. and Ucko, P. J., 'Tuberculosis in Ancient Egypt', Amer. Rev. Resp. Dis., 1964, 90, 524-541.

PIKe, A. W., 'The study of helminths from ancient cess-pit and latrine deposits: a new dimension in the study of early parasites,' Diseases in Antiquity, Springfield, Illinois, 1967.

Plimmer, H. G., 'Sir Armand Ruffer, C.M.G.,' Nature (Lond.), 1917, 99, 209-210.

Ritchie, J. R. and Williamson, G. S., 'Sir Marc Armand Ruffer,' J. Path. Bact., 1918-19, 22, 401-402.

Rowling, J. T., Disease in Ancient Egypt: evidence from pathological lesions found in mummies, M.D. thesis , Univ. of Cambridge, 1961.

RuFFer, M. A., 'Notes on the histology of Egyptian mummies', Brit. med. J., 1909, i, 1005.

Idem., 'Remarks on the histology and pathological anatomy of Egyptian mummies', Cairo Sci. J., 1910a, 4, 1-5.

Idem., "Note on the presence of "Bilharzia haematobia" in Egyptian mummies of the Twentieth Dynasty (1250-1000 B.C.)', Brit. med. J., 1910b, 1, 16.

Idem., 'Histological studies on Egyptian mummies', Mém. Inst. Egypte, Cairo, 1911a, 6 (3).

Idem., 'On arterial lesions found in Egyptian mummies (1580 B.C.-525 A.D.)', J. Path. Bact., $1911 b, 15,453-462$.

Idem., 'On dwarfs and other deformed persons in Ancient Egypt', Bull, Soc. Archéol. Alex., 1911c, 13, 1-17.

Idem., 'On pathological lesions found in Coptic bodies', J. Path. Bact., 1913, 18, 149-162.

Idem., 'Pathological notes on the Royal Mummies of the Cairo Museum', Mitt. Gesch. Med. Naturw., 1914a, 13, 239-268.

Idem., 'Note on diseases of the Sudan and Nubia in ancient times', Mitt. Gesch. Med. Naturw., 1914b, 13, 453-460.

Idem., 'Arthritis deformans and spondylitis in Ancient Egypt', J. Path. Bact., 1918a, 22, $152-196$.

Idem., 'Some recent researches on prehistoric trephining', J. Path. Bact., 1918b, 22, 90-104.

Idem., 'On the physical effects of consanguineous marriages in the Royal Families of Ancient Egypt', Proc. roy. Soc. Med., 1919, 12 1-46.

Idem., 'Abnormalities and pathology of Ancient Egyptian teeth', Amer. J. phys., Anthrop., 1920a, 3, 335-382. 


\section{A.T. Sandison}

Idem., 'A pathological specimen dating from the Lower Miocene Period', Extrait de Contributions a l'Etude des Vertebres miocenes de l'Egypte: Cairo Survey Department, $1920 \mathrm{~b}$.

Idem., Studies in the Palaeopathology of Egypt, ed. by R. L. Moodie, Chicago, 1921. (This contains reprints of all Ruffer's papers on palaeopathological subjects).

Ruffer, M. A. and Ferguson, A. R., 'Notes on an eruption resembling that of Variola in the skin of a mummy of the 20th Dynasty', J. Path. Bact., 1910, 15, 1-3.

Ruffer, M. A. and RIETti, A., 'Notes on two Egyptian mummies dating from the Persian Occupation of Egypt', Bull. Soc. Archéol. Alex., 1912, 14, 1-18.

Idem., 'On osseous lesions in Ancient Egyptians', J. Path. Bact., 1912, 16, 439-465.

RufFer, M. A. and Willmore, J. G., 'Note on a tumour of the pelvis dating from Roman times (A.D. 250) and found in Egypt', J. Path. Bact., 1914, 18, 480-484.

RYDER, M. L., 'Follicle arrangement in skin from wild sheep, primitive domestic sheep and in parchment', Nature (Lond.), 1958, 182, 781-783.

Sandison, A. T., 'The histological examination of mummified material', Stain Technol., $1955,30,277-283$.

Idem., 'Preparation of large histological sections of mummified tissues', Nature (Lond.) 1957, 179, 1309-1310.

Idem., 'Persistence of sudanophilic lipid in sections of mummified tissue', Nature (Lond.), $1959,183,196-197$.

Idem., 'Degenerative vascular disease in the Egyptian Mummy', Med. Hist., 1962, 6, 77-81.

Idem., 'Staining of vascular elastic fibres in mummified and dried human tissues', Nature (Lond.), 1963a, 198, 597.

Idem., 'The use of natron in mummification in Ancient Egypt', J. Near East. Stud., 1963b, 22, 259-267.

Idem., 'Pathological changes in the skeletons of earlier populations due to acquired disease, and difficulties in their interpretation', Symposium on the Biology of Earlier Human Populations, in press.

Shatrock, S. G., 'A report on the pathological condition of the aorta of King Merneptah', Proc. roy. Soc. Med., 1909, 2, 122-127.

Smith, G. Eluot, The Royal Mummies, Cairo, 1912.

SMITH, G. Elliot and JoNES, F. Wood, 'Report on the human remains', Archaeol. Surv. of Nubia Report 1907-8, Cairo, 1910.

SMITH, G. Elliot and RuFFer, M. A., 'Pott'sche Krankheit an einer Agyptschen Mumie aus der Zeit der 21 Dynastie (Um 1000 V. Chr.)', in Zur historischen Biologie der Krankheits erreger, ed. Sudhoff und Sticker, Heft 3, Giessen, 1910.

Wells, C., Bones, Bodies and Diseases, London, 1964.

WILDER, H. H., 'The restoration of dried tissues with special reference to human remains', Am. Anthrop., 1904, 6, 1-17.

Wilson, G. E., 'A study in American palaeopathology', Am. Natur., 1927, 61, 555-565.

ZORAB, P. A., 'The historical and prehistorical background of ankylosing spondylitis', Proc. roy. Soc. Med., 1961, 54, 415-420. 